\title{
SELEÇÃO E OBTENÇÃO DE EXTRATOS DE PLANTAS PARA UTILIZAÇÃO NO CONTROLE DE PRAGAS NA AGRICULTURA FAMILIAR
}

\author{
Raimundo Clístenes Marques de Souza ${ }^{1}$; Walter Santos Evangelista Júnior ${ }^{2}$ \\ ${ }^{1}$ Discente do Curso de Agronomia, Faculdade de Ciências Agrárias de Marabá (FCAM), Universidade Federal do Pará \\ (UFPA), Marabá, Pará. Bolsista PARD. E-mail: mrkronus_mk@ hotmail.com. \\ ${ }^{2}$ D.Sc., FCAM, UFPA. E-mail: wevangelista@ufpa.br.
}

RESUMO: A agricultura familiar tem o milho como uma das suas principais culturas de subsistência. Dentre as pragas dessa cultura Spodoptera. Frugiperda (Lepidoptera: Noctuidae) destaca-se como a principal. Para o seu controle, os agricultores utilizam o controle químico. Como alternativa para diminuir a aplicação de agrotóxicos surge a utilização de produtos naturais que são menos agressivos ao homem, aos animais e ao ambiente, com destaque para os inseticidas de origem vegetal. Os extratos de plantas surgem como objeto de pesquisa sendo uma alternativa no manejo integrado de pragas. Extratos botânicos apresentam vantagens sobre os agrotóxicos como biodegradação. $\mathrm{O}$ objetivo desta pesquisa é selecionar plantas com potencial inseticida para o controle da $S$. frugiperda. Serão selecionadas plantas de ocorrência regional e de fácil disponibilidade para os agricultores. Os extratos vegetais serão obtidos de folhas, sementes e ramos de, no mínimo, cinco plantas a serem selecionadas. Para comparação do efeito inseticidas dessas plantas será utilizados extratos da plantas de nim A. indica, planta conhecida mundialmente. Os extratos das plantas serão extraídos por via aquosa e etanólica. O efeito dos extratos das plantas sobre S. frugiperda será testado por contato e ingestão. Por contato os extratos serão pulverizados sobre as lagartas e por ingestão os extratos serão pulverizados sobre as folhas de milho e posteriormente as mesmas serão oferecidas às lagartas. Serão utilizadas lagartas no segundo e terceiro estádio onde será avaliada a sobrevivência e a viabilidade larval. Será utilizado delineamento inteiramente casualizado com 10 repetições. As analises serão realizadas com o Sistema de análises estatística SAEG 9.0. Ao final desta pesquisa espera-se obter, ao menos, duas plantas regionais da Amazônia como matéria prima para obtenção de inseticidas naturais a serem utilizados pelos agricultores em cultivos de subsistência e estabelecer uma metodologia de manejo integrado de pragas sem a utilização de agrotóxicos, visando principalmente ações que englobem o controle alternativo (inseticidas naturais) e o controle biológico. Dentre as contribuições oriundas desta pesquisa pode-se dividi-las em científicas e tecnológicas, as cientificas são a geração de artigos científicos; geração de conhecimento de plantas com poder inseticidas que servirão como base para pesquisas futuras; caracterização e conhecimento sobre a bioecologia da S. frugiperda; treinamento de estudantes na identificação e/ou diagnose das principais pragas na cultura do milho; a prioridade nas apresentações será para os bolsistas de graduação, como parte do programa de treinamento discente que será selecionado posteriormente; envolvimento interinstitucional entre a Universidade Federal do Pará (UFPA), Campus Universitário de Marabá e Altamira e da Empresa Brasileira de Pesquisa Agropecuária (EMBRAPA/Amazônia Oriental - Belém). As inovações tecnológicas são implementação de programa de Manejo de Pragas na cultura do milho por meio da utilização de produtos menos tóxico ao agricultor a ao meio ambiente; possibilitar que produtores de milho do município de Marabá-Pará tenham acesso a informações e assistência técnica; benefícios gerados pelo presente estudo abrangerão tanto o aspecto social, por meio de treinamento e capacitação de pessoal, como econômico, considerando-se a alta possibilidade de obtenção do sucesso no manejo integrado de pragas e redução do uso de agrotóxicos.

PALAVRAS-CHAVE: Planta inseticida, controle alternativo, Spodoptera frugiperda. 